\title{
Disinfection of drainwater from soilless cultures by heat treatment
}

\author{
W. Th. Runia' ${ }^{1}$ E. A. van Os ${ }^{2}$ and G. J. Bollen ${ }^{3}$ \\ ${ }^{1}$ Glasshouse Crops Research Station, P.O. Box 8, NL 2670 AA Naaldwijk, \\ Netherlands; ' Institute of Agricultural Engineering, P.O. Box 43, NL 6700 AA \\ Wageningen, Netherlands; ${ }^{3}$ Department of Phytopathology, Agricultural Uni- \\ versity, P.O. Box 8025, NL 6700 EE Wageningen, Netherlands
}

Received 7 January 1988; accepted 14 April 1988

Key words: hydroponics, drainwater, disinfection, disinfestation, heat inactivation, heat exchanger, tobacco mosaic virus, Fusarium oxysporum f. sp. melongenae, Verticillium dahliae

\begin{abstract}
In closed systems with soilless cultures, recirculation of drainwater offers favourable conditions for the spread of root-infecting pathogens. An installation was designed for disinfection of drainwater by heat treatments at high temperatures (more than $90{ }^{\circ} \mathrm{C}$ ) for short periods (approx. $10 \mathrm{sec}$ ). The energy input was low because of efficient use of heat exchangers. Preliminary results of glasshouse experiments, in which test plants were used as a bioassay, showed that tobacco mosaic virus and Verticillium dahliae were effectively controlled. Results of laboratory and glasshouse experiments indicate that probably longer exposure times are required for complete elimination of Fusarium oxysporum f. sp. melongenae.
\end{abstract}

\section{Introduction}

In the Netherlands, the area of soilless cultures in glasshouses increased to more than 2000 ha during the last five years. Especially for vegetable crops with only a few plants per $\mathrm{m}^{2}$. like tomatoes, cucumbers, sweet peppers and eggplants, it is economically interesting to grow them in artificial substrates.

Mainly three systems are practised: (1) the open drainage system, (2) the trough system with substrate slabs, (3) the nutrient film technique (NFT). With the open drainage system, which is the most common one and covers more than $90 \%$ of the area, rockwool slabs enveloped with polyethylene foil are placed upon a polyethylene sheet covering the soil. Plants - in rockwool blocks - are placed upon the slabs and intermittently watered by means of trickle-irrigation.

The excess of water and nutrients, given to balance the variation in transpiration 
and nutrient needs of the plants and the variable release of the individual capillaries, flows directly into the soil. For economical reasons (no waste of water and nutrients) and to avoid pollution of soil and surface water, it is preferable to collect and reuse this excess nutrient solution (drainwater). Reuse of drainwater implies that a closed recirculation system should become part of the standard growing system, which requires some type of trough system.

A disadvantage of recirculating the nutrient solution in the trough system is the risk of spreading root-infecting pathogens all through the system. Therefore, the drainwater has to be disinfected before its reuse. One of the methods of disinfection is heat treatment. Therefore disinfection equipment was developed in which the nutrient solution is passed through heat exchangers and treated to establish the temperature and exposure time required for elimination of pathogens. Heat exchangers are widely used for pasteurization of milk.

The existing data on temperature-time exposures lethal to pathogens are mainly based on assessment of viability of propagules treated in watery or saline suspensions and on their survival during heat treatment of infested soil. For two reasons, the existing data on lethal temperatures cannot merely be applied to predict the effectivity of disinfection of nutrient solutions by using heat exchangers. First, because in these exchangers heating and cooling-down is realized in a very short period (less than $1 \mathrm{~min}$ ), whereas with soil-steaming the treatment lasts from 0.5 to $6 \mathrm{~h}$ and with solarization even a few weeks. Secondly, the medium in which the pathogens are heated is different, viz. nutrient solution or soil solution. Data on temperature-time exposures required for heat inactivation of pathogens in nutrient solution by short treatments are not available.

This article presents the preliminary results of a study on the phytopathological and technical aspects of the application of the disinfection equipment.

\section{Disinfection equipment: technical aspects}

For the elaboration of the design of the disinfection installation, the following assumptions have been made:

- crops are grown in artificial substrate slabs lying in troughs,

- the water given to the plants is of good quality, in order to prevent phytotoxicity caused by high levels of sodium and chloride,

- watering is by trickle-irrigation, with a maximum of 20 tricklings of 2-3 minutes per 24 hours,

- the quantity of drainwater amounts to $25 \%$ of the quantity of nutrient solution dosed per day,

- there is a maximum water supply of $71 \mathrm{~m}^{-2} \mathrm{day}^{-1}$, resulting in a daily quantity to be disinfected of $18 \mathrm{~m}^{3} \mathrm{ha}^{-1}$ and an estimated annual quantity of $1800 \mathrm{~m}^{3} \mathrm{ha}^{-1}$,

- the nutrient solution returns from the plants with a temperature of about $20^{\circ} \mathrm{C}$ and is cooled down after disinfection to $30^{\circ} \mathrm{C}$.

A scheme of the installation (designed by N. J. van de Braak, Institute of Agricultural Engineering; unpublished) is shown in Fig. 1. The excess of nutrient solution (drainwater) returning from the plants is collected in a recatchment tank. From 


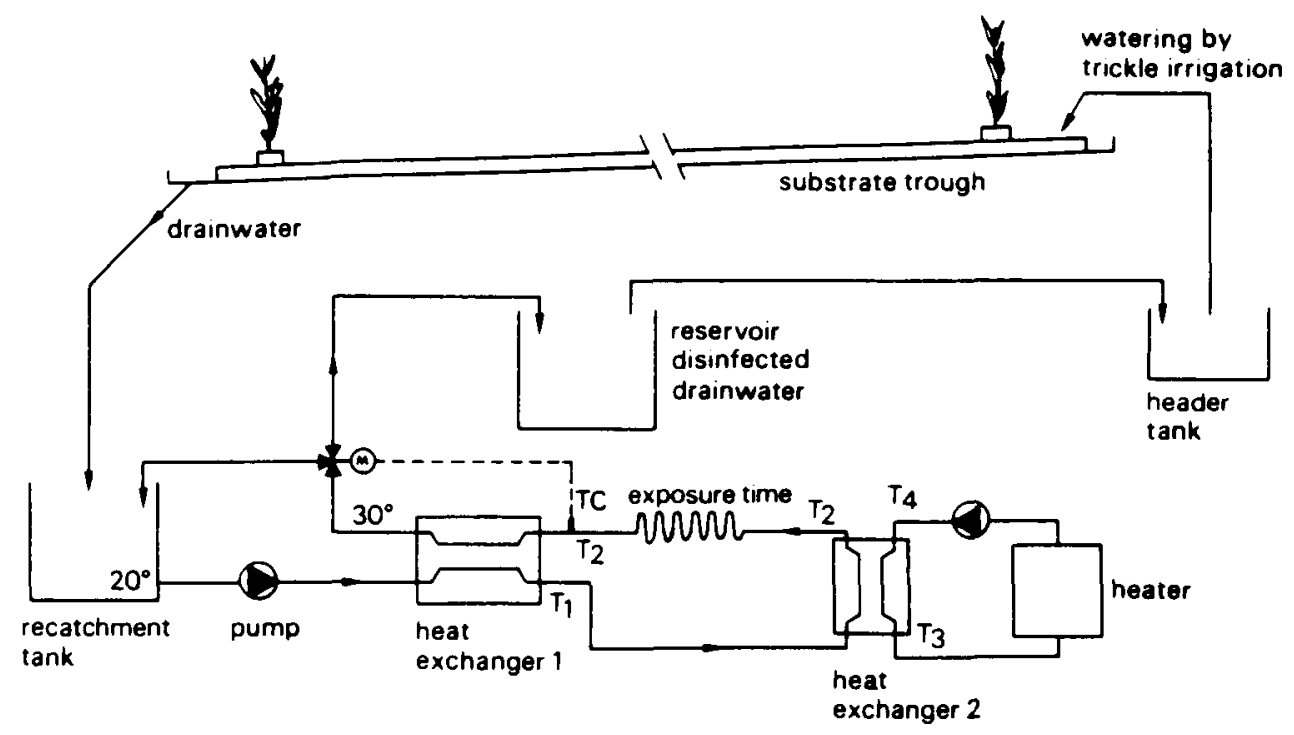

Fig. 1. Scheme of the disinfection installation. Temperatures based on the results in the present paper: $\mathrm{T} 1: 80^{\circ} \mathrm{C}<\mathrm{T} 1<90^{\circ} \mathrm{C}, \mathrm{T} 2:>95^{\circ} \mathrm{C}, \mathrm{T} 3: 90^{\circ} \mathrm{C}<\mathrm{T} 3<95^{\circ} \mathrm{C}, \mathrm{T} 4: 105^{\circ} \mathrm{C}$. M: motor-driven valve. TC: thermocouple.

this tank the solution is pumped into heat exchanger 1 , where it is preheated to $\mathrm{T} 1$ by heat recovery from disinfected water. In heat exchanger 2 the solution is heated to the disinfection temperature (T2), using an external heat source. The disinfected solution flows back to heat exchanger 1 to be cooled down and subsequently it is stored in a separate reservoir. From this reservoir it is pumped to the header tank where it is mixed with the standard nutrient solution.

The drainwater returns discontinuously during the day, which means that several restarts of the installation must be made. To assure that all water in the installation is properly disinfected, a switching valve is installed in order to return the insufficiently treated water to the recatchment tank.

The capacities of the heat exchangers are dependent on the temperature needed for disinfection of drainwater. These data are based on the results of the experiments on heat inactivation of root-infecting pathogens.

Because the equipment is exposed to nutrient solution at high temperatures it must be built of corrosion-free materials like stainless steel and synthetic materials. Materials containing copper and zinc cannot be used because of phytotoxicity.

\section{Heat inactivation of root-infecting pathogens}

\section{Introduction}

According to the present experience with vegetables grown in soilless cultures in 
Dutch glasshouses, the root-infecting pathogens are the same as those occurring in crops grown in soil. The main root-infecting fungi are Verticillium dahliae in tomato and pythiaceous fungi and Fusarium oxysporum in various crops. Olpidium radicale can be added to this list, because symptoms of melon necrotic spot virus (MNSV), the virus transmitted by zoospores of this fungus, frequently appeared in cucumber crops in soilless cultures. The main root-infecting viruses in crops in soilless cultures are cucumber green mottle mosaic virus (CGMMV) in cucumber, and tobacco mosaic virus (TMV) in sweet pepper, eggplant, cherry-tomato and some beef-tomato cultivars.

The thermal inactivation point (TIP) of viruses, that is the temperature required for complete inactivation following 10 minutes exposure, is established in a crude sap extract (Hill, 1984). For different strains of TMV, the TIP is above $90{ }^{\circ} \mathrm{C}$ (Zaitlin \& Israel, 1975).

Laboratory experiments were set up to establish lethal temperatures by shortlasting treatments. F. oxysporum f. sp. melongenae was chosen as a test fungus, because the formae speciales of $F$. oxysporum were among the most resistant fungal pathogens in a previous study (Bollen, 1985). It can presumptively be concluded that treatments that are lethal to this pathogen will also eradicate pythiaceous fungi and $V$. dahliae.

Heat resistance of TMV, $V$. dahliae and $F$. oxysporum $\mathrm{f}$. sp. melongenae was also assessed in glasshouse experiments using a prototype of the disinfection apparatus.

\section{Methods}

In the laboratory experiments, cultures of $F$. oxysporum $\mathrm{f}$. $\mathrm{sp}$. melongenae were grown on malt agar (MA) at $20^{\circ} \mathrm{C}$ or in shaking cultures with Czapek Dox solution. After 3 days of incubation, the plates were exposed to daylight in order to promote formation of macroconidia.

Before treatment, the spores were suspended in previously sterilized drainwater sampled from soilless cultures ( $\mathrm{pH} 5.4 ; \mathrm{EC} 1.9 \mathrm{dS} \mathrm{m}^{-1}\left(25^{\circ} \mathrm{C}\right)$ ). The density was $10^{h}$ spores $\mathrm{ml}^{-1}$ or higher. The suspension was transferred to culture tubes, which were placed in a thermostatic stirring waterbath. In the first experiment, 18-mm-diam. tubes (wall $1.5 \mathrm{~mm}$ ) were used, because of the relatively long period needed for warming up the suspension (Table 1); smaller tubes (diam. $9.5 \mathrm{~mm}$ ) with a thin wall $(0.6 \mathrm{~mm})$ were used in subsequent experiments (Tables 2 and 3$)$. In order to avoid contamination of the suspension, temperatures were measured with thermocouples placed in tubes of replicates treated for the same time in the same way.

Survival of the spores was tested with dilution plates. A dilution series of the suspension with tenfold steps were made and $0.1 \mathrm{ml}$ was added to each plate of potato dextrose agar (PDA). Four plates were used for each dilution.

The spore suspensions prepared from young cultures contained micro- and macroconidia. Suspensions with chlamydospores were prepared from 3- or 8-month-old shaking cultures, of which the mycelium was fragmented in the drainwater using a blender.

In the glasshouse experiments, the disinfection apparatus heated the drainwater 
in about $2 \mathrm{~s}$ to the temperature required. The exposure time was about $10 \mathrm{~s}$. During the heat treatment, temperatures were measured using thermocouples and a thermorecorder. Temperatures of untreated drainwater varied from 16 up to $26^{\circ} \mathrm{C}$. while after treatment the drainwater was cooled down to $21-25^{\circ} \mathrm{C}$.

Suspensions of TMV, isolate SD, strain 0 were added to the drainwater in the recatchment tank. Pure and crude virus extracts were $10^{3}$ and $10^{5}$ times diluted with drainwater. The TMV suspensions were heated to $97 \pm 2{ }^{\circ} \mathrm{C}$. The infectivity of the TMV suspensions was established by rubbing samples of each treatment on carborundum-dusted leaves of three 4-6-week-old Nicotianae glutinosa plants.

Similar experiments were done with $V$. Dahliae and $F$. oxysporum $\mathrm{f}$. sp. melongenae. Conidial suspensions were obtained by culturing the fungi one week in liquid Czapek Dox at $26^{\circ} \mathrm{C}$. A suspension of $V$. dahliae with $2 \times 10^{7}$ spores $\mathrm{ml}^{-1}$ was diluted in drainwater to $2 \times 10^{5}$ and to $2 \times 10^{4}$ spores $\mathrm{ml}^{-1}$ and heated to $90 \pm 2{ }^{\circ} \mathrm{C}$ and $83 \pm 2{ }^{\circ} \mathrm{C}$, respectively. A suspension of $F$. oxysporum $\mathrm{f}$. sp. melongenae with $7 \times$ $10^{6}$ spores $\mathrm{ml}^{-1}$ was diluted to $7 \times 10^{\dagger}$ and $7 \times 10^{3}$ spores $\mathrm{ml}^{-1}$ drainwater and heated to $94 \pm 2{ }^{\circ} \mathrm{C}$. The infectivity of the spore suspensions was established by dipping the root-systems of 50 seedlings of eggplant cv. Dobrix into it, after which the seedlings were planted in a potting soil mixture.

\section{Results}

The suspensions of $F$. oxysporum f. sp. melongenae used in the laboratory tests were prepared from 3- and 8-month-old cultures. These cultures contained numberous chlamydospores; the mycelium was almost completely lysed. Probably most of the spores in the 8-month-old culture had lost their viability since $1 \mathrm{ml}$ of the untreated suspension containing $4 \times 10^{6}$ spores $\mathrm{ml}^{-1}$ yielded $33 \times 10^{3}$ colonies. From the data shown in Tables 1 and 2 , it is concluded that heating the suspension to $80^{\circ} \mathrm{C}$ within $1 \mathrm{~min}$ and keeping it at this temperature for $30 \mathrm{~s}$ is sufficient to kill the conidia and chlamydospores in both the 3-and 8-month-old shaking cultures.

The response to heating of spores from the 29-day-old cultures showed an irregular pattern: for the three temperatures of the treatment more spores survived a treatment for $2 \mathrm{~min}$ than those for shorter lasting exposures (Table 3 ). Effectivity of the treatment seemed not be correlated with its intensity. This response was not always found; it was evident in five out of twelve trials with $F$. oxysporum f. sp. melongenae and after treatments given to young spores only. Similar results were obtained for $F$. oxysporum $\mathrm{f}$. sp. lycopersici and $V$. dahliae. Until now, we failed to define the conditions determining this irregular response.

In the glasshouse trials. TMV was eliminated by treatments of $95{ }^{\circ} \mathrm{C}$ or more during $10 \mathrm{~s}$, because no local lesions were observed on the test plants inoculated with treated drainwater whereas all control plants contracted the disease. Spores of $V$. dahliae in a dilution of $10^{5}$ spores $\mathrm{ml}^{-1}$ were killed at $90{ }^{\circ} \mathrm{C}$ whereas the untreated spores caused 47 diseased eggplants out of 50 test plants. A spore suspension of $V$. dahliae with $10^{5}$ spores $\mathrm{ml}^{-1}$ lost its infectivity after treatment at $83{ }^{\circ} \mathrm{C}$ during $10 \mathrm{~s}$, because after inoculation with this suspension the test plants did not show any wilting symptoms whereas the untreated suspension in drainwater caused $80 \%$ dis- 
eased eggplants. In the experiments with $F$. oxysporum $\mathrm{f}$. sp. melongenae, apparently some spores survived the heat treatment. One out of 50 test plants dipped into the treated suspensions with $7 \times 10^{4}$ spores $\mathrm{ml}^{-1}$ showed wilting symptoms and so did three eggplants at the $7 \times 10^{3}$ spores $\mathrm{ml}^{-1}$ dilution. Nearly all control plants became diseased (Table 4).

Table 1. Viable counts, mean ( \pm s.d.), per $\mathrm{ml}$ of heat-treated suspensions of chlamydospores of $F$. oxysporum f. sp. melongenae in drainwater. The spores were harvested from a 3-month-old shaking culture.

\begin{tabular}{lllll}
\hline $\begin{array}{l}\text { Exposure } \\
\text { time }(\min )^{1}\end{array}$ & $\begin{array}{l}\text { Untreated } \\
\text { suspension }\end{array}$ & \multicolumn{3}{l}{ Heat-treated suspension; temperature $\left({ }^{\circ} \mathrm{C}\right)$} \\
\cline { 3 - 4 } & $22( \pm 5) \times 10^{7}$ & 59.0 & 74.2 & 80.2 \\
0 & & $1( \pm 3)$ & $1( \pm 1)$ & 0 \\
2 & & 0 & $1( \pm 1)$ & 0 \\
5 & & 0 & 0 \\
\hline
\end{tabular}

Warming up the suspension to the temperature of treatment took 4 min.

Table 2. Viable counts, mean ( \pm s.d.), per $\mathrm{ml}$ of heat-treated suspensions of chlamydospores of $F$. oxysporum f. sp. melongenae in drainwater. The spores were harvested from a 8-month-old shaking culture.

\begin{tabular}{|c|c|c|c|c|c|}
\hline \multirow{2}{*}{$\begin{array}{l}\text { Exposure } \\
\text { time }(\min )^{1}\end{array}$} & \multirow{2}{*}{$\begin{array}{l}\text { Untreated } \\
\text { suspension }\end{array}$} & \multicolumn{4}{|c|}{ Heat-treated suspension; temperature $\left({ }^{\circ} \mathrm{C}\right)$} \\
\hline & & 50.5 & 63.6 & 73.0 & 80.3 \\
\hline 0 & $33( \pm 22) \times 10^{3}$ & $30( \pm 5) \times 10^{3}$ & $21( \pm 5) \times 10$ & $3( \pm 5)$ & $3( \pm 5)$ \\
\hline 0.5 & & $30( \pm 4) \times 10^{3}$ & $6( \pm 3) \times 10$ & $15( \pm 13)$ & 0 \\
\hline 2.0 & & $16( \pm 5) \times 10^{3}$ & $1( \pm 2) \times 10$ & 0 & 0 \\
\hline
\end{tabular}

1 Warming up the suspension to the temperature of treatment took $1 \mathrm{~min}$.

Table 3. Viable counts, mean ( \pm s.d.), per $\mathrm{ml}$ of heat-treated suspensions of conidia and chlamydospores of $F$. oxysporum $\mathrm{f}$. sp. melongenae in drainwater. The spores were harvested from a 29 -day-old culture on MA plates.

\begin{tabular}{llllc}
\hline $\begin{array}{l}\text { Exposure } \\
\text { time }(\min )^{1}\end{array}$ & $\begin{array}{l}\text { Untreated } \\
\text { suspension }\end{array}$ & \multicolumn{3}{l}{ Heat-treated suspension; temperature $\left({ }^{\circ} \mathrm{C}\right)$} \\
\cline { 3 - 5 } & 69.5 & 81.5 & 90.0 \\
0 & $21( \pm 2) \times 10^{4}$ & $65( \pm 78)$ & $15( \pm 10)$ & 0 \\
0.5 & & $23( \pm 10)$ & $25( \pm 38)$ & $5( \pm 10)$ \\
2.0 & & $81( \pm 23) \times 10^{2}$ & $13( \pm 4) \times 10^{2}$ & $110( \pm 29)$ \\
4.0 & & - & - & 0 \\
\hline
\end{tabular}

${ }^{1}$ Warming up the suspension to the temperature of treatment took $1 \mathrm{~min}$. 
Table 4. Infectivity ${ }^{1}$ of TMV, $V$, dahliae and $F$. oxysporum f. sp. melongenae in drainwater after heat treatment at 10 seconds exposure time.

\begin{tabular}{|c|c|c|c|c|}
\hline Pathogen & Dilution & $\begin{array}{l}\text { Untreated } \\
\text { suspension }\end{array}$ & $\begin{array}{l}\text { Treated } \\
\text { suspension }\end{array}$ & $\begin{array}{l}\text { Temperature } \\
\left({ }^{\circ} \mathrm{C}\right)^{2}\end{array}$ \\
\hline TMV, pure & $10^{3}$ & $3 / 3$ & $0 / 3$ & 97 \\
\hline TMV , crude & $10^{3}$ & $3 / 3$ & $0 / 3$ & 97 \\
\hline TMV, pure & $10^{5}$ & $3 / 3$ & $0 / 3$ & 97 \\
\hline TMV, crude & $10^{5}$ & $3 / 3$ & $0 / 3$ & 97 \\
\hline$V$. dahliae & $2 \times 10^{5}$ spores $\mathrm{ml}^{-1}$ & $47 / 50$ & $0 / 50$ & 90 \\
\hline$V$. dahliae & $2 \times 10^{+}$spores $\mathrm{ml}^{-1}$ & $40 / 50$ & $0 / 50$ & 83 \\
\hline F. oxysporum & $7 \times 10^{4}$ spores $\mathrm{ml}^{-1}$ & $50 / 50$ & $1 / 50$ & 94 \\
\hline F. oxysporum & $7 \times 10^{3}$ spores $\mathrm{ml}^{-1}$ & $49 / 50$ & $3 / 50$ & 94 \\
\hline
\end{tabular}

1 Number of diseased plants/number of test plants.

${ }^{2}$ Given temperature $\pm 2{ }^{\circ} \mathrm{C}$.

\section{Discussion}

The disinfection equipment for a standard situation of 1 hectare and a continuous disinfection at a maximum water supply requires a heater capacity of $9 \mathrm{~kW}$. This means a usage of about $1.5 \mathrm{~m}^{3}$ natural gas per $\mathrm{m}^{3}$ drainwater. Calculated on an annual basis, the disinfection installation uses approx. $2700 \mathrm{~m}^{3}$ gas per hectare. The energy input is low because of the efficiency realized by the use of heat exchangers. The exposure time could be extended to $30 \mathrm{~s}$ or more by using longer tubes in the system between the heat exchangers 2 and 1 .

The installation is based on $25 \%$ drain. In nurseries this percentage varies from 15 to $50 \%$. Therefore, daily disinfection may vary up to $36 \mathrm{~m}^{3} \mathrm{ha}^{-1}$. This amount does not apply to other systems where much more water is in circulation. In the flooding system for pot plants, approx. $200 \mathrm{~m}^{3} \mathrm{ha}^{-1}$ has to be disinfected daily; in NFT systems, the disinfection capacity increases to $1000 \mathrm{~m}^{3} \mathrm{ha}^{-1} \mathrm{day}^{-1}$. Therefore, drainwater disinfection by heat treatment is not feasible in these growing systems.

Exposure of the drainwater to high temperatures in the heat exchangers increases precipitation of calcium salts. Therefore, it is recommended to wash the installation for five minutes with an acid solution with a $\mathrm{pH}$ of about 2 . In our experiments nitric acid was used.

The cause of the irregular pattern in the survival of the fungal spores in the laboratory tests is not understood. It is currently studied whether the spore suspensions contain a fraction of heat-resistant spores of which the dormancy is broken by a heat treatment or that formation of heat shock proteins as described by Plesofsky-Vig \& Brambl (1985) is involved. Whatever the mechanism may be, the survival of spores, albeit at a very low level, implies that the advice to disinfect at 80 or even $90^{\circ} \mathrm{C}$ for $30 \mathrm{~s}$ cannot be given unreservedly.

On nurseries, organic particles from roots and leaves must be filtered out of the 
drainwater before heat treatment in order to prevent blocking of the channels in the heat exchangers. Moreover, elimination of virus particles in plant parts requires much more time than the $10 \mathrm{~s}$ realized in the heating installation (Runia, 1986).

It must be noticed that in the glasshouse experiments, pathogens were added to the drainwater. Inoculum released from infected plants within the trough system may differ in its resistance and infectivity. A general and definite conclusion can only be drawn when the data acquired are supplemented with those obtained in systems with severely diseased plants in a long-term research.

In crops susceptible to root-infecting pathogens, it is advised to keep the disinfection temperature at $95^{\circ} \mathrm{C}$ at an exposure time of at least $10 \mathrm{~s}$, but preferably $30 \mathrm{~s}$, until more data are available.

\section{Acknowledgements}

The authors wish to thank Mrs C. C. M. M. van Veen-Stijger and Messrs A. Baädilla, G. L. van Charante, D. Diederik, P. Geurtsen, G. Lokhorst, S. J. Paternotte and R. Vijftigschild for their contribution to this study.

\section{References}

Bollen, G. J., 1985. Lethal temperatures of soil fungi. In: C. A. Parker, A. D. Rovira, K. J. Moore \& P. T. W. Wong (Eds), Ecology and management of soilborne plant pathogens. p. 191-193. American Phytopathological Society, St-Paul, USA.

Hill, S. A., 1984. Basic virus characterization and storage. In: T. F. Preece (Ed.), Methods in plant pathology. Vol. 1. Methods in plant virology. p. 19-20. Blackwell Scientific Publ., London.

Plesofsky-Vig, N. \& R. Brambl, 1985. The heat shock response of fungi. Experimental Mycology 9: 187194.

Runia, W. th., 1986. Disinfection of substrates used in protected cultivation. Soilless Culture 2: $35-44$.

Zaitlin, M. \& H. W. Israel, 1975. Tobacco mosaic virus (type strain). In: B. D. Harrison \& A. F. Murant (Eds), Descriptions of plant viruses, Nr 151, p. 3, Commonwealth Mycological Institute and Association of Applied Biologists, Kew, England. 